\title{
Marriage Dissolution (Divorce) - A Comparison Overview: Albania, Kosovo, Macedonia
}

\author{
Sulejman Ahmedi \\ Prof. Dr, State University of Tetova
}

\section{Abstract}

The research includes the marriage dissolution and its consequences, which constitute today one of the most debated topics, considering not only the significant increase of the number of divorces in years, but also the trends in recent years in some European countries. Thus, this paper presents the hypothesis as follows: The Institute of dissolution of marriage in Albanian, Kosovo and Macedonian Law which preserves and must preserve the balance between the contractual freedom of the spouses and the court's intervention to dissolve the marriage in order to avoid abuses that may result from the "privatization" of the marriage dissolution and its consequences. Taking the cause precisely from the latter, the question arises whether the dissolution of marriage, as the institution that lies between private and public law, should be given priority to the solutions offered by the spouses ("the privatization of the institution"), or should public law be governed by the regulation of the institution, in the context of the special protection that the marriage and family enjoy by the State? From what is said above it is necessary to analyze by comparative approach the normative framework, legal doctrine and the case studies of these countries, regarding the dissolution of the marriage and the consequences it brings. The European countries and the tendency to harmonize family law in Europe will serve as orientation point to analyze the solutions currently offered by Albanian, Kosovo and Macedonian law as well as to provide the necessary recommendations. In particular, the subject of analysis is the reasons for the dissolution of marriage, the ways and the procedural aspects of its solution, the consequences on both personally and property terms between the spouses.

Keywords: marriage, marriage dissolution (divorce), consequences of marriage dissolution, "privatization" of marriage dissolution

\section{Introduction}

Preliminary consideration is that the marriage is a basic institution not only for the private interest of the spouses or their children, but also the public, which is interested in the family's safety and survival (Omar, 2010: 187). Problems related to 
the dissolving of marriage are of a theoretical and practical nature. Demographic data in Europe show a decrease in the number of marriages and an increase in the number of marital dissolutions as a result of changes in the legislation of member countries, which increasingly recognize the right of cohabiting couples. ${ }^{1}{ }^{2}$ In contemporary societies, the marriage is not a communion that must last forever and continue even when close emotional relationships between spouses as a basis for family and spousal life do not function (Fantetti, 2011: 128-131). No matter how one might see it, there is a reality that can not be denied, which is that between spouses, disagreements may still arise. To avoid such "unbearable life", special attention has been paid since the ancient times of mankind's history, for the juridical regulation of marriage, and also for its resolution.lt is pointless to insist strongly that a marriage should be kept alive for a couple in a situation where it is established that the conjugal life has become meaningless and unsteady. Therefore, divorce is considered as a way out of a state characterized by a worsening of the conjugal relations. Today, the legal provisions of various countries maintain an interim stand between the complete prohibition of marriage and permission to end marriage. Family life does not end when the couple ends in divorce or when the parties do not live together (Kilkelly, 2003: 19). Moreover, the marriage resolution and the consequences derived from it in regulating family life are dealt with in the dual context of private law and public law. The first relates to the regulation of private relationships that arise from marriage; the second, with the special protection that the family and the marriage enjoy from the State. This is because the family created by marriage as an important subsystem of society for its proper functioning is indispensable for the existence and reproduction of the social community (Omari, 2010: 187). Issues related to dissolution of the marriage are current, not only in the countries subject of analysis, but also on an international and European level. Organizations organized since ancient times have regulated the dissolution of the marriage with legal norms from Roman, Greek, Byzantine, Egyptian, etc., as well as Albanian customary law. In the contemporary European era, the data in which we can refer to and ascertain that the marriage settlement was legally regulated derive since XVII. Although marriage implies a legal union and coexistence between a couple with a prospective to be stable, unique and long-lasting, this does not always happen in practice. On the contrary, there are many cases where the need for divorce is born, since social life, in fact marital life in society, has different dimensions and dynamics. Like the question of marriage resolution, which is going through a constant change, the same dynamic has followed the definition of the juridical nature of dissolution of marriage (Puhan, 1969: 184). The dissolution of marriage is closely related to marriage and its relation: every social relationship, once created, needs to be regulated and defined in terms of the conditions, causes and ways

\footnotetext{
${ }^{1}$ For statistical data in Europe see: Marriage and divorce statistics, on http://ec.europa.eu/eurostat/statistics- explained/index.php/Marriage and divorce statistics, seen on December 20, 2015.

2 Marriage, according to this doctrinal power, was defined as the link between a man and a woman that refers to an indissoluble common life.
} 
of its extinction (Vasilev \& Haxhi, 1980: 126). The right to divorce is a completely personal right and belongs exclusively to the spouses. Although marriage is related to the will of the spouses, its dissolution must be made according to the legal rules and husband and wife cannot solve it on their own (Zaçe, 1996: 18). In order for the marriage to be able to end definitively, there must be reasons determined by law and legal procedure, to be resolved by the final judgment of the competent state body, specifically the court (Podvorica, 2006: 120). Divorce may only be required as long as the two spouses are alive. The supposition mentioned must exist for the entire duration of the divorce proceedings. From this definition, these are the most important features of marriage divorce:

a) a valid marriage is legally dissolved;

b) a marriage is dissolved during the common life;

c) the court, as a rule, as the competent state body, makes the decision on divorce, ${ }^{1}$

d) the reasons for the termination of marriage should be provided by law;

Marriage as a juridical act, sui generis, which differs from other legal actions based on the contractual freedom of the parties, is resolved by a court decision and not with the consent of the spouses. According to the KFRSI-I (Family Code of the Republic of Albania) from 1982, the courts were obliged to mention the causes that had caused the shock of marital relations and to determine the spouse for whose fault the marriage was resolved. Some of these reasons are as follows: maltreatment; severe insults; the violation of adultery; incurable psychic illness; penal punishment of one of the spouses; other causes that may shake the marriage to an extent of such deterioration, that their common life is impossible, and the marriage has lost its purpose, etc. (Begeja, 1985: 270). Divorce can only be made for reasons foreseen by law. According to Article 53 of the Constitution of the Republic of Albania, "Everyone has the right to marry and have a family. Marriage and family enjoy the special protection of the state. Creating and resolving a marriage is regulated by law." According to Article 37 of the Constitution of the Republic of Kosovo, "Marriage and its resolution are regulated by law and are based on the equality of spouses." The legislations of Macedonia, Albania and Kosovo have adopted a mixed system which foresees the general causes and particular causes for seeking divorce. The causes leading to divorce are different in character and nature. For example, from the 2007 statistics analysis in Macedonia, the doctrine (Mughal, 2015: 102-103) ranked among the reasons justifying the high number of marriages and at the same time the low number of divorces, those religious and cultural norms that morally condemn performing sexual relations outside the marital relationship. In Albania, recent

\footnotetext{
1 There is a tendency in Europe to expand the autonomy of the parties to resolve the marriage (when there are no juveniles) to resolve the marriage even without a court decision (for example, with the assistance of a lawyer or notary).
} 
sociological studies (Molla, 2015: 449) list domestic violence, unemployment and migration among the social and economic causes, this in turn leads to the cooling of couples' relationships and the violation of adultery. The legislation of the Republic of Macedonia is expressed in terms of worsening marital relations to the extent that common life has become unbearable (Article 40 of the LFRM - Family Law of the Republic of Macedonia), but in contrast to Albanian legislation does not list specific causes. LFRK (Family Law of the Republic of Kosovo) is similar to LFRM (Family Law of the Republic of Macedonia) because it does not list specific causes but refers to serious or persistent disorder of marital or other causes, as a result of

which marriage is irretrievably resolved (Article 69/1 LFRK). The Kosovo Jurisprudence emphasized that: Marriage should be maintained only when there is a mutual love of spouses, which is also reflected in their harmonious coexistence and the wish of one husband is not enough to preserve it (Trial Judgment Bulletin, 2013: 918). ${ }^{1}$

The legal logic requires that in the judgment on the divorce of the spouse, the court is obliged to determine whether the relationships are broken to the extent that the conjugal life is unbearable. This means that it is necessary to ascertain the reasons for reaching the dissolution of the marriage (Totaj \& Hamzaj, 2009: 111)2. If there are three ways to resolve marriage in all three countries, the reasons for marital divorce are numerous and, depending on their types, the law also provides for the procedure to be followed in each case as well as the consequences that arise of them. It is often the case that the court is placed in the face of an analysis of facts, behaviors, and nonfulfillment of rights and obligations which are generally considered as a breach of marriage obligations. Statistics in the study countries show that the worsening of spousal relationships is on the rise, for various reasons. ${ }^{3}$ The procedure for marriage dissolution, in all three countries, is regulated by the Family Code (or the Family Law) and the civil procedure law of the states in question. Marriage will be considered dissolved only after the competent court will make a decision on this, assessing the fulfillment of the conditions set forth in the material law. Family issues are quite sensitive, especially in the divorce proceedings because of the personal rights and duties of spouses and other family members. Therefore, the lawmaker has foreseen

\footnotetext{
1 See the decision of the Supreme Court of the Republic of Kosovo (Judgment, Ac No. 65/2012) of 29 October 2012, which rejected as ungrounded the Applicant's appeal and upheld the Judgment of the District Court in Prizren C. no. 125/2012 of July 27, 2012.

2 The doctrine defines the unseen secular causes of divorce, such as those that are presented naturally and as such cannot be borne by any of the spouses (such as character mismatches, different approaches, etc.)

${ }^{3}$ See, Statistical Review on the Resolution of the Marriage (Divorce) in the Republic of Albania, the Republic of Kosovo as well as in the Republic of Macedonia
} 
the principles to be respected during the conduct of this procedure, the court's competence. ${ }^{1}$

\section{Conclusion}

The categorization of the consequences arising after the dissolution of marriage on the occasion of the dissolution of marriage ends the legal relationship between the spouses, created as a result of the marriage bond. In this sense, dissolution of marriage represents a legal fact with the authentication of which the law provides for extinction of martial relationship. From the analysis of the institute of dissolution of marriage in the comparative examination results an increase in the number of marital dissolution in all three countries. The comparison between Kosovo and Macedonia shows that the number of the dissolution of marriage is higher in the latter and that fictitious marriages are a widespread phenomenon in these countries. Among the main factors affecting the dissolution of marriage for the three countries in the analysis rank such migration and the economic reasons. The current normative regulation in Albania, Kosovo and Macedonia is presented as more traditional and conservative. This is evidenced in the decisive role that the legislation of the countries subject to analysis attributes to public intervention limiting the contractual freedom of spouses to dissolution of marriage. My opinion is that this approach should be preferred in order to protect the family core from a "privatization" of the dissolution of marriage carried out in an expedited procedure, which contradicts the purpose of the special protection that the marriage and the family enjoy from State. This is intended not only to preserve family values but also to avoid possible abuses, especially in fictitious marriages.

\section{Bibliography}

[1] Abazi I, et al., (1996) E drejta familjare në Islam, Shkup.

[2] Abdul'ati H \& Haxhi., (1995) Struktura familjare në Islam, Shkup.

[3] Aliu A., Gashi H., (2007) E drejta familjare, Prishtinë: Universiteti i Prishtines..

[4] Amram M., D’Angelo A., (2011). La famiglia e il diritto fra diversity nazionali ed iniziative dell'Unione Europea, Milano: Cedam.

[5] Auletta T., (2007). Bilanci e prospettive di dititto di famiglia a trenf anni dalla riforma, Milano: Giuffrë.

[6] Bakic V., (1979). Porodicno pravo, dvanaesto dopolneto i izmeneto izdanie, Beograd: Savremena administracija.

[7] De Singley F.R., (1985) Sociologie de la famille conteporaine, Paris: Edithion Nathan.

[8] Elezi I., (2006) Kanuni i Labërisë, Tiranë: Toena.

\footnotetext{
1 Thus, for example, Article 30, paragraph 2, point 1, Law on the Courts of the Republic of Macedonia (Official Gazette of the Republic of Macedonia, No.58/06, 35/08,150/10) defines the substantive competence of the basic courts which are competent to adjudicate for the termination of marriage.
} 